\title{
Screening of underlying genetic biomarkers for ankylosing spondylitis
}

\author{
XUTAO FAN ${ }^{1}$, BAO $^{1}{ }^{1}$, LONGFEI MA $^{2}$ and FENGYU MA ${ }^{3}$ \\ ${ }^{1}$ Department of Spine Surgery, Affiliated Hospital of Jining Medical University, Jining, Shandong 272029; \\ ${ }^{2}$ Graduate School of Jining Medical University, Jining, Shandong 272067; ${ }^{3}$ Department of Spine Surgery, \\ People's Hospital of Rizhao, Rizhao, Shandong 276800, P.R. China
}

Received August 6, 2018; Accepted March 6, 2019

DOI: $10.3892 / \mathrm{mmr} .2019 .10188$

\begin{abstract}
Genetic biomarkers for the diagnosis of ankylosing spondylitis (AS) remain unreported except for human leukocyte antigen B27 (HLA-B27). Therefore, the aim of the present study was to screen the differentially expressed genes (DEGs), and those that also possess differential single nucleotide polymorphism (SNP) loci in the whole blood of AS patients compared with healthy controls by integrating two mRNA expression profiles (GSE73754 and GSE25101) and SNP microarray data (GSE39428) collected from the Gene Expression Omnibus (GEO). Using the t-test, 1,056 and 1,073 DEGs were identified in the GSE73754 and GSE25101 datasets, respectively. Among them, 234 DEGs were found to be shared in both datasets, which were subsequently overlapped with 122 differential SNPs of genes in the GSE39428 dataset, resulting in identification of two common genes [eukaryotic translation elongation factor 1 epsilon 1 (EEF1E1) and serpin family A member 1 (SERPINA1)]. Their expression levels were significantly upregulated and the average expression $\log \mathrm{R}$ ratios of SNP sites in these genes were significantly higher in AS patients than those in controls. Function enrichment analysis revealed that EEF1E1 was involved in AS by influencing the aminoacyl-tRNA biosynthesis, while SERPINA1 may be associated with AS by participating in platelet degranulation. However, only the genotype and allele frequencies of SNPs (rs7763907 and rs7751386) in EEF1E1 between AS and controls were significantly different between AS and the controls, but not SERPINA1. These findings suggest that EEFIE1 may be an underlying genetic biomarker for the diagnosis of AS.
\end{abstract}

Correspondence to: Mr. Xutao Fan, Department of Spine Surgery, Affiliated Hospital of Jining Medical University, 89 Guhuai Road, Jining, Shandong 272029, P.R. China

E-mail: fxtspine@163.com

Key words: ankylosing spondylitis, genetic biomarker, single nucleotide polymorphism, differentially expressed genes

\section{Introduction}

Ankylosing spondylitis (AS) is a common inflammatory rheumatic disease, with an estimated prevalence (per 10,000) of 23.8 in Europe, 16.7 in Asia, 31.9 in North America, 10.2 in Latin America and 7.4 in Africa (1). AS mainly affects the spine and sacroiliac joints in the pelvis to cause low back pain, stiffness and functional disability, which seriously influence the quality of life of patients and impose a heavy economic burden on both family and society (2). Therefore, there is a need for the timely diagnosis and effective treatment of AS.

Although the pathogenesis remains not clearly defined, accumulating evidence has suggested that AS is highly heritable. Human leukocyte antigen (HLA)-B27, a class I surface antigen encoded by B locus in the major histocompatibility complex (MHC) on the short (p) arm of chromosome 6, is one of the convincing genetic factors associated with AS (3). HLA-B27 was reported to be present in $94.3 \%$ of patients with AS, but only $9.34 \%$ in organ donors (4). The expression of $H L A-B 27$ was found to be significantly higher in patients with AS than that in healthy subjects (5). Meta-analyses indicated that $H L A-B 27$ genetic polymorphism B2704 and B2702 may be risk factors, while B2703, B2706, B2707, B2727, B2729 and B2747 may be protective factors for AS (6,7). HLA-B27-positive patients had a significantly younger age at symptom onset, more uveitis, and a higher frequency of peripheral and hip joint involvement than HLA-B27-negative patients $(7,8)$. Thus, $H L A-B 27$ has been the most commonly used biomarker for the diagnosis of AS (9). However, twin and family studies suggest that $H L A-B 27$ only can explain less than $30 \%$ of the overall risk for AS $(10,11)$, meaning there are other genes related with the genetic disorder of AS. Recently, scholars have also aimed to investigate other inflammatory biomarkers for AS, including interleukin (IL)-8 (12), tumor necrosis factor $(T N F)-\alpha(13)$, C-reactive protein $(h s C R P)(14)$ and C-C motif chemokine 11 (CCL11) (15), but studies that have focused on the genetic biomarkers are limited $(16,17)$.

The aim of the present study was to integrate the microarray data of mRNA and the single nucleotide polymorphism (SNP) expression profile in whole blood of AS patients and healthy controls to screen for differentially expressed genes (DEGs), and those that also possess differential SNP loci, 
which has not been previously performed. These SNP-related DEGs may be crucial genetic biomarkers for AS.

\section{Materials and methods}

Microarray data. Three microarray datasets under accession nos. GSE73754 (18), GSE25101 (19) and GSE39428 $(20,21)$ were downloaded from the Gene Expression Omnibus (GEO) database (http://www.ncbi.nlm.nih.gov/geo/). GSE73754 (platform: GPL10558; Illumina HumanHT-12 V4.0 expression BeadChip) detected the gene expression profile in whole blood samples from $52 \mathrm{AS}$ and 20 healthy controls; GSE25101 (platform: GPL6947; Illumina HumanHT-12 V3.0 expression BeadChip) compared the gene expression profile in whole blood samples between 16 AS and 20 healthy controls; and GSE39428 (GPL15779; Illumina custom human SNP VeraCode microarray) analyzed the SNPs in 384 genes of $51 \mathrm{AS}$ and 163 healthy controls.

Data normalization. For the two expression data from the Illumina platform, the TXT. data were downloaded and preprocessed using the Linear Models for Microarray data (LIMMA) method (22) (version 3.34.0; http://www.bioconductor.org/packages/release/bioc/html/limma.html) in the Bioconductor R package (version 3.4.1; http://www.R-project. org/), including base-2 logarithmic ( $\log 2)$ transformation and quantile normalization. The SNP signal spectrum in the GSE39428 dataset was preprocessed using hidden Markov model (HMM)-based program PennCNV (23) (version 1.0.4; http://penncnv.openbioinformatics.org/en/latest/), including the following steps: i) the signal intensity of the A and B alleles in each SNP were extracted and quantile normalized using the quantile method; ii) the normalize_affy_geno_cluster.pl procedure in the PennCNV package was used to calculate the $\log \mathrm{R}$ ratio (LRR) and $\mathrm{B}$ allele frequency (BAF) in each SNP, resulting in the generation of baf. files; the kcolumn.pl procedure in the PennCNV package was utilized to split the baf. files to signal intensity of single sample; the copy number variation $(\mathrm{CNV})$ was detected using the detect_cnv.pl procedure in the PennCNV package.

Differential analysis of $m R N A s$ and SNPs. The DEGs between control and AS in the GSE73754 and GSE25101 datasets were identified using the LIMMA method (22) based on the t-test where statistical significance was set to $\log \mathrm{FC}$ (fold change) $>0.263$ and Benjamini and Hochberg adjusted (24) false discovery rate (FDR) $<0.05$. Hierarchical clustering heatmap illustrating the expression intensity and direction of the common DEGs in two mRNA datasets was constructed using the pheatmap R package (version 1.0.8; https://cran.r-project. org/web/packages/pheatmap) based on Euclidean distance. The differential SNPs were screened by comparing the LRR between AS and controls by using the Student's t-test. The genotype and allele frequencies of SNPs in DEGs between AS and controls were also compared using the Chi-square test (or Fisher's exact test), with P-value $<0.05$ set as the threshold value.

PPI (protein-protein interaction) network construction. The interaction pairs of the common DEGs were retrieved from the STRING 10.0 (Search Tool for the Retrieval of Interacting

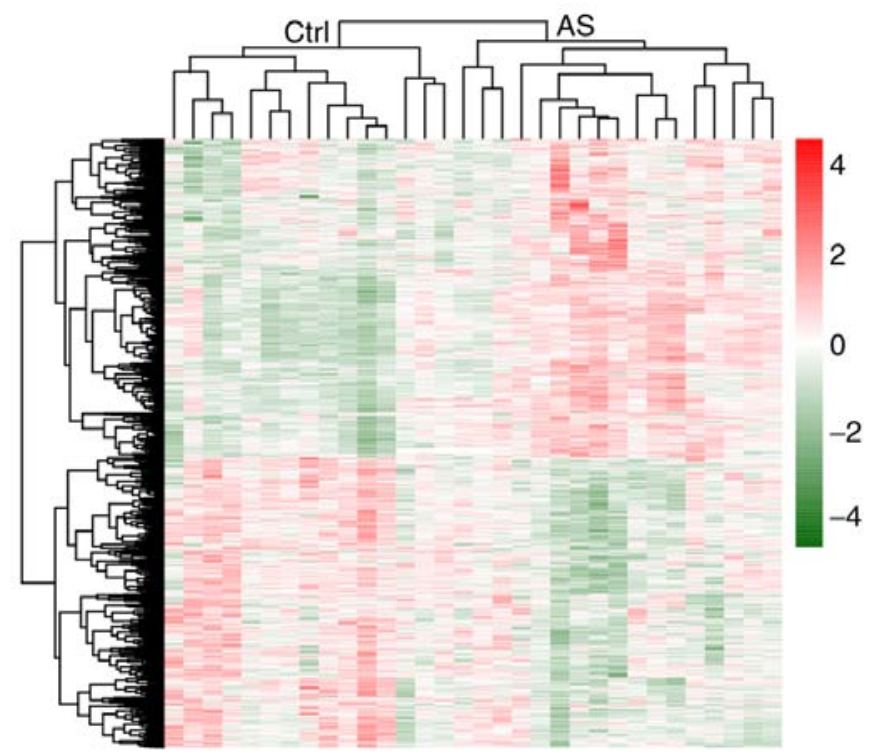

Figure 1. Hierarchical clustering heat map analysis of the common differentially expressed genes in two mRNA expression profile datasets (GSE73754 and GSE25101). AS, ankylosing spondylitis; Ctrl, control. Red indicates high expression; green indicates low expression.

Genes; http://string db.org/) database (25) and then the PPI network was visualized using the Cytoscape software (version 3.6.1; www.cytoscape.org/) (26). Four topological characteristics of the genes in the PPI network, including degree [the number of edges (interactions) of a node (protein)], betweenness centrality (BC, the number of shortest paths that run through a node), closeness centrality (CC, the average length of the shortest paths between one node and any other node in the network) and average path length (APL, the average of distances between all pairs of nodes), were calculated using the CytoNCA plugin in Cytoscape software (http://apps. cytoscape.org/apps/cytonca) (27), the overlapped genes of the top 35 in four parameters were suggested as crucial genes.

To identify functionally related and highly interconnected clusters from the PPI network, module analysis was carried out by using the Molecular Complex Detection (MCODE) plugin of Cytoscape software under the followed parameters: Degree cutoff $=2$, Node score cutoff $=0.2$ and K-core $=2$ (ftp://ftp. mshri.on.ca/pub/BIND/Tools/MCODE) (28).

Function enrichment analysis. The underlying functions of common DEGs between two mRNA datasets, genes in the PPI and modules enrichment analyses were predicted using the Database for Annotation, Visualization and Integrated Discovery (DAVID) online tool (version 6.8; http://david.abcc. ncifcrf.gov). $\mathrm{P}<0.05$ was chosen as the threshold to determine the significantly enriched Kyoto Encyclopedia of Genes and Genomes (KEGG) pathways and Gene Ontology (GO) terms which were visualized using $\mathrm{R}$ language.

\section{Results}

Identification of DEGs. Based on the threshold (FDR $<0.05$ and $\mid \log \mathrm{FCl}>0.263$ ), a total of 1,056 and 1,073 DEGs were identified between AS and controls for GSE73754 and GSE25101 datasets, respectively. After comparison analysis, 


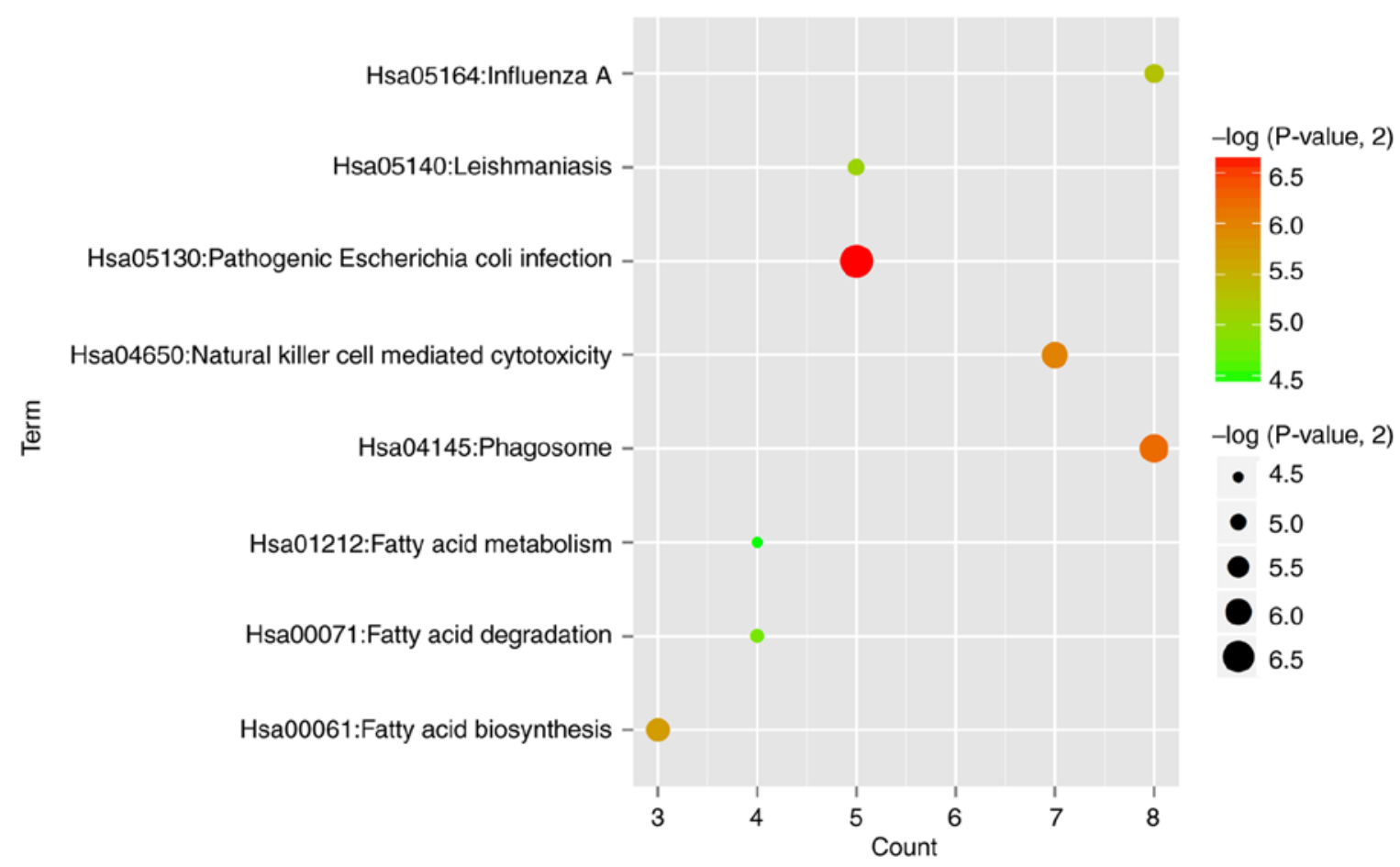

Figure 2. KEGG pathways enrichment for the common differentially expressed genes in two mRNA expression profile datasets (GSE73754 and GSE25101). The horizontal axis is the count of genes that are enriched in the pathways; the vertical axis indicates the KEGG pathways; the circle indicates the level of significance (P-value). KEGG, Kyoto Encyclopedia of Genes and Genomes.

105 upregulated and 129 downregulated DEGs were found to be shared in both two datasets. The hierarchical clustering heatmap suggested that these 234 common DEGs could well distinguish AS from control samples (Fig. 1).

Function enrichment analysis for the common DEGs. DAVID database was used to predict the underlying functions of the common DEGs. The results showed that 8 significant KEGG pathways (Fig. 2) were enriched, such as hsa05130:Pathogenic Escherichia coli infection (TLR4, toll like receptor 4) and hsa04145:Phagosome (TLR4) (Table I). In addition, 23 significant GO biological process (BP) terms including GO:0006418 tRNA aminoacylation for protein translation (EEF1E1, eukaryotic translation elongation factor 1 epsilon 1; YARS, tyrosyl-tRNA synthetase), GO:0051092 positive regulation of $\mathrm{NF}-\kappa \mathrm{B}$ transcription factor activity (TLR4), GO:0050776 regulation of immune response (KLRD1, killer cell lectin like receptor D1), and GO:0032715 negative regulation of interleukin-6 production (TLR4); 6 significant GO molecular function (MF) terms, consisting of GO:0005515 protein binding (SERPINA1, serpin family A member 1; TLR4); and 6 significant GO molecular function (MF), such as GO:0005515 protein binding (SERPINA1, EEF1E1); 26 GO cell component (CC) terms, including GO:0070062 extracellular exosome (SERPINA1, EEF1E1), GO:0005737 cytoplasm (EEF1E1) and GO:0005829 cytosol (EEF1E1); were enriched (Fig. 3 and Table I).

PPI network. After mapping the DEGs to the STRING database, 356 interaction pairs were obtained which were used for constructing the PPI network where 154 nodes (64 upregulated and 88 downregulated) were included (Fig. 4).
By calculating degree, $\mathrm{BC}, \mathrm{CC}$ and $\mathrm{APL}$, and comparing genes ranked as the top 30, HDACl (histone deacetylase 1), $Y A R S, E P R S$ (glutamyl-prolyl-tRNA synthetase), APEX1 (apurinic/apyrimidinic endodeoxyribonuclease 1), ACTG1 (actin $\gamma$ 1), MDH2 (malate dehydrogenase 2), TNF (tumor necrosis factor), CCT3 (chaperonin containing TCP1 subunit 3), TLR4 (Toll-like receptor 4), TUBB (tubulin $\beta$ class I), FCGR2A (Fc fragment of IgG receptor IIa), KLRDI (killer cell lectin-like receptor D1) and FASN (fatty acid synthase) were found to be shared by these 4 topological characteristics, suggesting they were hub genes for AS (Tables II and III).

Subsequently, four functionally related and highly interconnected modules were screened (Fig. 5). The genes in module 1 were associated with aminoacyl-tRNA biosynthesis (YARS) (Fig. 5A); the genes in module 2 were related with natural killer cell mediated cytotoxicity $(K L R D I)$ and immune response (KLRDI) (Fig. 5B); the genes in module 3 were relevant with metabolic pathways (EPRS) (Fig. 5C); and the genes in module 4 were enriched in GO terms of platelet degranulation (SERPINA1) (Fig. 5D) (Table IV).

Integration of SNP microarray and expression profile data. The LRR of each SNP for 384 genes in AS and control samples was computed. The LRR in most samples were lower than 1 , indicating the presence of copy number deletions. Subsequently, the statistical difference in LRR of each SNP between AS and control samples were determined by Student's t-test, with 122 differential SNP identified. After overlapping the genes having differential SNP with the DEGs, two common genes (EEF1E1 and SERPINA1) were obtained. SERPINA1 was upregulated in AS (Fig. 6A) and the average expression LRR of the rs6575424 polymorphism in AS samples was 
Table I. Function enrichment for the differentially expressed genes between patients with ankylosing spondylitis and controls.

\begin{tabular}{|c|c|c|c|}
\hline Category & Term & P-value & Genes \\
\hline KEGG_PATHWAY & $\begin{array}{l}\text { hsa05130:Pathogenic } \\
\text { Escherichia coli infection }\end{array}$ & $9.97 \mathrm{E}-03$ & $A C T G 1, T U B B, E Z R, T L R 4, T U B A 1 B$ \\
\hline KEGG_PATHWAY & hsa04145:Phagosome & $1.36 \mathrm{E}-02$ & $\begin{array}{l}\text { ACTG1, TUBB, NCF4, TLR4, FCGR } 2 A, \\
M 6 P R, T U B A 1 B, H L A-D R A\end{array}$ \\
\hline KEGG_PATHWAY & $\begin{array}{l}\text { hsa04650: Natural killer cell } \\
\text { mediated cytotoxicity }\end{array}$ & $1.58 \mathrm{E}-02$ & $\begin{array}{l}\text { IFNAR2, TNFSF 10, TNF, CD247, KLRD1, } \\
\text { SH2D1B, HCST }\end{array}$ \\
\hline KEGG_PATHWAY & hsa00061:Fatty acid biosynthesis & $1.90 \mathrm{E}-02$ & ACSL1, FASN, ACSL4 \\
\hline KEGG_PATHWAY & hsa05164:Influenza A & $2.56 \mathrm{E}-02$ & $\begin{array}{l}\text { ACTG1, IFNAR2, TNFSF10, TNF, MAP } 2 K 4, \\
T L R 4, I V N S 1 A B P, H L A-D R A\end{array}$ \\
\hline KEGG_PATHWAY & hsa05140:Leishmaniasis & $3.01 \mathrm{E}-02$ & $T N F, N C F 4, T L R 4, F C G R 2 A, H L A-D R A$ \\
\hline KEGG_PATHWAY & hsa00071:Fatty acid degradation & $3.63 \mathrm{E}-02$ & ACSL1, ECHS1, ACSL4, ALDH9A1 \\
\hline KEGG_PATHWAY & hsa01212:Fatty acid metabolism & $4.52 \mathrm{E}-02$ & ACSL1, FASN, ECHS1, ACSLA \\
\hline GOTERM_BP_DIRECT & $\begin{array}{l}\text { GO:0007166 cell surface } \\
\text { receptor signaling pathway }\end{array}$ & $5.44 \mathrm{E}-05$ & $\begin{array}{l}C D 8 A, C D 247, E V L, B I R C 2, A D G R G 1, \\
I F N A R 2, T N F S F 10, A D R B 2, K L R G 1, N U P 62, \\
T D P 2, C D 81, C D A, K L R D 1\end{array}$ \\
\hline GOTERM_BP_DIRECT & $\begin{array}{l}\text { GO:0006418 tRNA } \\
\text { aminoacylation for protein } \\
\text { translation }\end{array}$ & $1.67 \mathrm{E}-03$ & YARS, EEF1E1, AARS, EPRS, QARS \\
\hline GOTERM_BP_DIRECT & $\begin{array}{l}\text { GO:0043123 positive } \\
\text { regulation of I-kappaB } \\
\text { kinase/NF-kappaB signaling }\end{array}$ & $4.76 \mathrm{E}-03$ & $\begin{array}{l}\text { CARD11, TNFSF 10, TNF, NUP62, PINK1, } \\
\text { CXXC5, BIRC2, S100A12 }\end{array}$ \\
\hline GOTERM_BP_DIRECT & $\begin{array}{l}\text { GO:0051092 positive } \\
\text { regulation of NF-kappaB } \\
\text { transcription factor activity }\end{array}$ & 7.34E-03 & $\begin{array}{l}\text { CARD11, IRAK3, NLRC4, TNF, PRKCH, } \\
\text { TLR4, S100A12 }\end{array}$ \\
\hline GOTERM BP_DIRECT_ & $\begin{array}{l}\text { GO:0050776 regulation of } \\
\text { immune response }\end{array}$ & $8.11 \mathrm{E}-03$ & $\begin{array}{l}\text { CARD11, CD96, CD8A, CD247, CD81, } \\
\text { KLRD1, SH2D1B, HCST }\end{array}$ \\
\hline GOTERM_BP_DIRECT & $\begin{array}{l}\text { GO:2001240 negative regulation } \\
\text { of extrinsic apoptotic } \\
\text { signaling pathway } \\
\text { in absence of ligand }\end{array}$ & $1.17 \mathrm{E}-02$ & $T N F, Z C 3 H C 1, M C L 1, C X 3 C R 1$ \\
\hline GOTERM_BP_DIRECT & $\begin{array}{l}\text { GO:0030890 positive } \\
\text { regulation of B cell proliferation }\end{array}$ & $1.35 \mathrm{E}-02$ & $C A R D 11, C D 81, T L R 4, A D A$ \\
\hline GOTERM_BP_DIRECT & $\begin{array}{l}\text { GO: } 2000377 \sim \text { regulation of } \\
\text { reactive oxygen species } \\
\text { metabolic process }\end{array}$ & $2.66 \mathrm{E}-02$ & TNF, PINK1, BIRC2 \\
\hline GOTERM_BP_DIRECT & $\begin{array}{l}\text { GO:0071353 cellular response } \\
\text { to interleukin-4 }\end{array}$ & $3.74 \mathrm{E}-02$ & $X B P 1, F A S N, T U B A 1 B$ \\
\hline GOTERM_BP_DIRECT & $\begin{array}{l}\text { GO:0032715 negative } \\
\text { regulation of interleukin- } 6 \\
\text { production }\end{array}$ & $4.96 \mathrm{E}-02$ & IRAK3, TNF, TLR4 \\
\hline GOTERM_MF_DIRECT & GO:0005515 protein binding & $3.50 \mathrm{E}-10$ & $\begin{array}{l}\text { PDLIM7, PPP2R5A, TLR1, CNOT2, TLR4, } \\
\text { RNF216, CCT3, ARIDIA, TGFA, SERPINA1 }\end{array}$ \\
\hline GOTERM_MF_DIRECT & $\begin{array}{l}\text { GO:0044822 poly }(\mathrm{A}) \\
\text { RNA binding }\end{array}$ & $1.11 \mathrm{E}-04$ & $\begin{array}{l}\text { ABCF1, CCT3, ZNF207, EXOSC10, HNRNPM, } \\
E Z R, F A S N, A P E X 1, Y A R S, M D H 2\end{array}$ \\
\hline GOTERM_MF_DIRECT & GO:0005524 ATP binding & $5.01 \mathrm{E}-03$ & $\begin{array}{l}A B C F 1, P I N K 1, M A P 4 K 1, Q A R S, C C T 3, \\
T R I B 1, A C T G 1, E P R S, A D K, E I F 4 A 1\end{array}$ \\
\hline GOTERM_MF_DIRECT & $\begin{array}{l}\text { GO:0042288 MHC class I } \\
\text { protein binding }\end{array}$ & $2.42 \mathrm{E}-02$ & $T U B B, C D 8 A, A T P 5 A 1$ \\
\hline GOTERM_MF_DIRECT & $\begin{array}{l}\text { GO:0031625 ubiquitin } \\
\text { protein ligase binding }\end{array}$ & $3.16 \mathrm{E}-02$ & $\begin{array}{l}\text { ACTG1, RPA2, TUBB, XBP1, SLC25A5, RALB, } \\
\text { PINK1, TUBA1B, TRIB1 }\end{array}$ \\
\hline GOTERM_MF_DIRECT & $\begin{array}{l}\text { GO:0047485 protein N-terminus } \\
\text { binding }\end{array}$ & $3.59 \mathrm{E}-02$ & RPA2, HDAC1, BIRC2, GLRX, FEZ1 \\
\hline GOTERM_CC_DIRECT & $\begin{array}{l}\text { GO:0070062 extracellular } \\
\text { exosome }\end{array}$ & $3.20 \mathrm{E}-06$ & $\begin{array}{l}\text { HIST2H2AA3, CAPZA2, PTGS1, CCT3, PDHB, } \\
\text { RTN3, ACTG1, N4BP2L2, CCNY, LILRA5 }\end{array}$ \\
\hline
\end{tabular}


Table I. Continued.

\begin{tabular}{|c|c|c|c|}
\hline Category & Term & P-value & Genes \\
\hline GOTERM_CC_DIRECT & GO:0005737 cytoplasm & $1.87 \mathrm{E}-05$ & $\begin{array}{l}\text { ABCF 1,C9ORF72,E2F3, PDLIM7, AGTPBP1, } \\
\text { PPP } 2 \text { RAA, PTGS1, CNOT2, PINK1, SHOC2 }\end{array}$ \\
\hline GOTERM_CC_DIRECT & GO:0005829 cytosol & $1.39 \mathrm{E}-04$ & $\begin{array}{l}\text { ABCF 1, AGTPBP1, CAPZA2, CNOT2, PINK1, } \\
D P H 2, R N F 216, Q A R S, A R H G A P 17, C C T 3\end{array}$ \\
\hline GOTERM_CC_DIRECT & $\begin{array}{l}\text { GO:0030529 intracellular } \\
\text { ribonucleoprotein complex }\end{array}$ & $2.73 \mathrm{E}-04$ & $\begin{array}{l}\text { ZFP36L2, HNRNPM, NUP62, CSNK1E, } \\
\text { RPL22, SNRPB, EPRS, DYRK2, HNRNPR }\end{array}$ \\
\hline GOTERM_CC_DIRECT & GO:0016020 membrane & $1.212 \mathrm{E}-03$ & $\begin{array}{l}\text { ABCF1, KCNJ15, GNAI3, TNF, MCL1, } \\
\text { PPP2R5A, CAPZA2, TLR1, CD247, CNOT2 }\end{array}$ \\
\hline
\end{tabular}

KEGG, Kyoto encyclopedia of Genes and Genomes; GO, Gene Ontology; BP, biological process; MF, molecular function; CC, cell component.

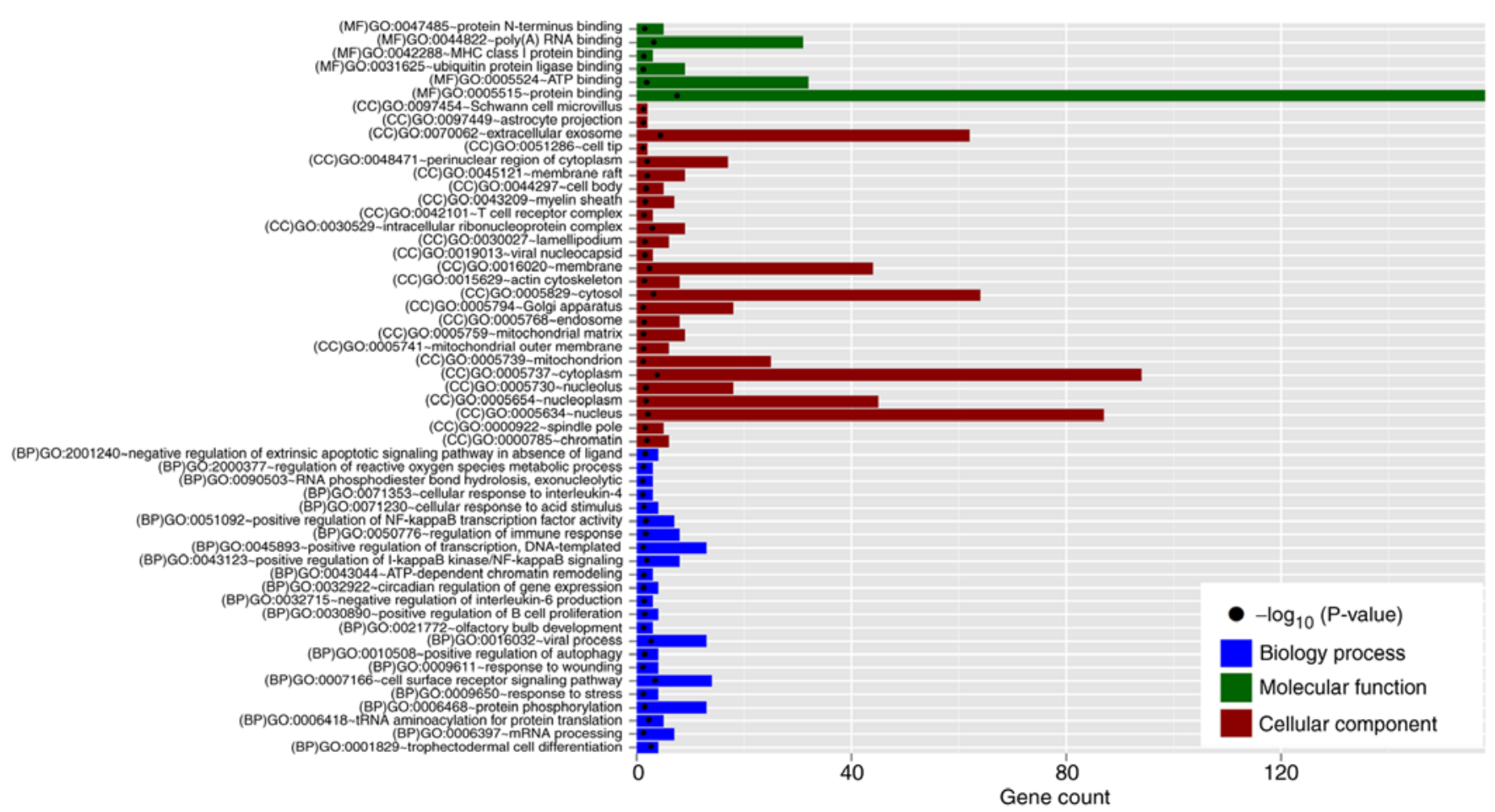

Figure 3. GO terms for the common differentially expressed genes in the two mRNA expression profile datasets (GSE73754 and GSE25101). The horizontal axis displays the count of genes that are enriched in the GO term; the vertical axis lists the GO terms. The circle indicates the level of significance (P-value). GO, Gene Ontology.

significantly higher than that in the controls (0.05 vs. -0.14 , $\mathrm{P}=6.57 \mathrm{E}-07$ ) (Fig. 6B); EEF1E1 was also upregulated in AS (Fig. 6A) and the average expression LRRs of rs7763907 ( -4.88 vs. $-5.91, \mathrm{P}=0.048)$, rs9328453 (0.07 vs. -0.12 , $\mathrm{P}=3.69 \mathrm{E}-05$ ) (Fig. 6B), rs7751386 (-0.85 vs. $-1.49, \mathrm{P}=2.52 \mathrm{E}-04)$, and rs 12660697 (0.08 vs. $-0.02, \mathrm{P}=0.02)$ polymorphisms in AS samples were significantly higher than that in controls.

Furthermore, the genotype and allele frequencies of SNPs in EEFIE1 and SERPINA1 between AS and controls were compared using the Chi-square (or Fisher's exact) test. The results showed there were significant differences in the genotype and allele frequencies of rs7763907 between AS and control samples. The genotype frequency of rs 7751386 between AS and control samples was also significantly differential. These findings suggest that these two polymorphic sites of the EEF1E1 gene may be associated with the susceptibility to acquire AS (Table V).

\section{Discussion}

In the present study, two crucial genes (EEFIEl and SERPINAI) were identified for the diagnosis of ankylosing spondylitis (AS) by analyzing two mRNA expression profile datasets and one single nucleotide polymorphism (SNP) dataset. Their expression levels were significantly upregulated and the average expression LRRs of SNP sites in these genes were significantly higher in AS patients that those in the controls. EEF1El was involved in AS by influencing aminoacyl-tRNA biosynthesis, while SERPINA1 may be associated with AS by participating in platelet degranulation. 
Table II. Topological characteristics.

\begin{tabular}{|c|c|}
\hline Genes & Value \\
\hline$T N F$ & 24 \\
\hline$E P R S$ & 19 \\
\hline$A C T G 1$ & 17 \\
\hline YARS & 16 \\
\hline$T L R 4$ & 14 \\
\hline$H D A C 1$ & 14 \\
\hline CCT7 & 14 \\
\hline NOP56 & 13 \\
\hline$M D H 2$ & 13 \\
\hline$I M P 3$ & 12 \\
\hline ССТЗ & 12 \\
\hline EIF4AI & 12 \\
\hline$A T P 5 A 1$ & 11 \\
\hline POLRIC & 11 \\
\hline GNAI3 & 10 \\
\hline$C S$ & 10 \\
\hline$A T I C$ & 10 \\
\hline APEX1 & 9 \\
\hline NOP2 & 9 \\
\hline$S N R P B$ & 9 \\
\hline$C D 247$ & 9 \\
\hline$K L R D 1$ & 9 \\
\hline$D D X 47$ & 8 \\
\hline$A A R S$ & 8 \\
\hline$M C L 1$ & 8 \\
\hline SRSF5 & 8 \\
\hline$T U B B$ & 8 \\
\hline FASN & 8 \\
\hline$F C G R 2 A$ & 7 \\
\hline
\end{tabular}

B, Closeness centrality

\begin{tabular}{|c|c|c|c|}
\hline & \multirow{2}{*}{$\begin{array}{l}E I F 4 A 1 \\
A D A\end{array}$} & \multirow{2}{*}{$\begin{array}{l}0.0558 \\
0.0508\end{array}$} \\
\hline Genes & Value & & \\
\hline KLHL2 & 1.0000 & $T U R B$ & \\
\hline$F B X O 21$ & 1.0000 & FCGR A & 0.0491 \\
\hline$G P B P 1$ & 1.0000 & & 0.0430 \\
\hline PLEKHF1 & 1.0000 & MDH2 & 0.0382 \\
\hline RTN3 & 1.0000 & $E Z R$ & 0.0360 \\
\hline$R R A G D$ & 1.0000 & CYB5R4 & 0.0359 \\
\hline$T N F$ & 0.4000 & CCT3 & 0.0337 \\
\hline$H D A C 1$ & 0.3946 & $P R K C H$ & 0.0316 \\
\hline$A C T G 1$ & 0.3852 & $M C L 1$ & 0.0315 \\
\hline ССТЗ & 0.3605 & $N U P 214$ & 0.0289 \\
\hline YARS & 0.3596 & HIST2H $2 A A 3$ & 0.0288 \\
\hline$E P R S$ & 0.3570 & SERPINAI & 0.0286 \\
\hline$A L D H 9 A 1$ & 0.3510 & $T D P 2$ & 0.0282 \\
\hline$F C G R 2 A$ & 0.3427 & SHOC2 & 0.0274 \\
\hline$M D H 2$ & 0.3387 & $M A P 4 K 1$ & 0.0273 \\
\hline
\end{tabular}

Table II. Continued.

$\mathrm{B}$, Closeness centrality

\begin{tabular}{lc}
\hline Genes & Value \\
\hline APEX1 & 0.3349 \\
ADA & 0.3333 \\
FASN & 0.3318 \\
$C S$ & 0.3288 \\
ATIC & 0.3281 \\
TLR4 & 0.3274 \\
EZR & 0.3244 \\
DDB1 & 0.3237 \\
$C C T 7$ & 0.3230 \\
AARS & 0.3223 \\
KLRD1 & 0.3216 \\
TUBB & 0.3216 \\
CYBSR4 & 0.3216 \\
\hline
\end{tabular}

C, Betweenness centrality

\begin{tabular}{|c|c|}
\hline Genes & Value \\
\hline$T N F$ & 0.2996 \\
\hline$A C T G 1$ & 0.2278 \\
\hline$H D A C 1$ & 0.1883 \\
\hline YARS & 0.0824 \\
\hline$E P R S$ & 0.0783 \\
\hline TLR4 & 0.0753 \\
\hline GNAI3 & 0.0745 \\
\hline$C D 247$ & 0.0743 \\
\hline$A P E X 1$ & 0.0688 \\
\hline$R A L B$ & 0.0622 \\
\hline$A L D H 9 A 1$ & 0.0559 \\
\hline EIF 4Al & 0.0558 \\
\hline$A D A$ & 0.0508 \\
\hline$F A S N$ & 0.0507 \\
\hline KLRDI & 0.0499 \\
\hline$T U B B$ & 0.0491 \\
\hline$F C G R 2 A$ & 0.0430 \\
\hline$M D H 2$ & 0.0382 \\
\hline$E Z R$ & 0.0360 \\
\hline$C Y B 5 R 4$ & 0.0359 \\
\hline ССТ3 & 0.0337 \\
\hline PRKCH & 0.0316 \\
\hline MCL1 & 0.0315 \\
\hline$N U P 214$ & 0.0289 \\
\hline$H I S T 2 H 2 A A 3$ & 0.0288 \\
\hline SERPINAI & 0.0286 \\
\hline$T D P 2$ & 0.0282 \\
\hline SHOC2 & 0.0274 \\
\hline$M A P 4 K 1$ & 0.0273 \\
\hline
\end{tabular}


Table II. Continued.

$\mathrm{D}$, Average path length

\begin{tabular}{|c|c|}
\hline Genes & Value \\
\hline$R N F 126$ & 1.0000 \\
\hline KLHL2 & 1.0000 \\
\hline$F B X O 21$ & 1.0000 \\
\hline$G P B P 1$ & 1.0000 \\
\hline PLEKHF 1 & 1.0000 \\
\hline RTN3 & 1.0000 \\
\hline$R R A G D$ & 1.0000 \\
\hline$T N F$ & 2.5000 \\
\hline$H D A C 1$ & 2.5342 \\
\hline$A C T G 1$ & 2.5959 \\
\hline ССТЗ & 2.7740 \\
\hline YARS & 2.7808 \\
\hline$E P R S$ & 2.8014 \\
\hline$A L D H 9 A 1$ & 2.8493 \\
\hline$F C G R 2 A$ & 2.9178 \\
\hline$M D H 2$ & 2.9521 \\
\hline$A P E X 1$ & 2.9863 \\
\hline$A D A$ & 3.0000 \\
\hline FASN & 3.0137 \\
\hline$C S$ & 3.0411 \\
\hline$A T I C$ & 3.0479 \\
\hline$T L R 4$ & 3.0548 \\
\hline$E Z R$ & 3.0822 \\
\hline$D D B 1$ & 3.0890 \\
\hline CCT7 & 3.0959 \\
\hline$A A R S$ & 3.1027 \\
\hline KLRDI & 3.1096 \\
\hline$T U B B$ & 3.1096 \\
\hline CYB5R4 & 3.1096 \\
\hline
\end{tabular}

EEF1E1, also known as aminoacyl-tRNA synthetaseinteracting multifunctional protein 3 (AIMP3/p18), was initially found to encode an auxiliary component of the macromolecular aminoacyl-tRNA synthase complex that catalyzes the ligation of a specific amino acid to its compatible cognate tRNA to form an aminoacyl-tRNA to initiate protein translation $(29,30)$. Thus, EEF1E1 may be upregulated to promote the development of various types of cancer (31). However, recent studies indicate that EEF1E1 may also function as a tumor-suppressor $(32,33)$ by upregulating the growth factor- or Ras-dependent induction of p53 $(34,35)$. Cells with loss of EEF1E1 were found to exhibit impaired p53 transactivity and genomic instability and thus were found to became susceptible to cell malignant transformation $(34,36)$, while overexpression of EEF1E1 induced cellular senescence phenotypes (37). It was also demonstrated that the p53 level was significantly higher in the peripheral blood supernatant of a rheumatoid arthritis (RA) group than the level in control groups and there was a positive correlation between p53 levels and the disease activity score in the RA group (38). In addition, in RA synovial tissues, $80 \%$ of p53-positive cells
Table III. Overlapping DEGs according to topological features (degree, closeness centrality, betweenness centrality and average path length).

\begin{tabular}{lc}
\hline Common genes & Expression \\
\hline HDAC1 & Down \\
$Y A R S$ & Down \\
EPRS & Down \\
$A P E X 1$ & Down \\
$A C T G 1$ & Down \\
$M D H 2$ & Down \\
$T N F$ & Down \\
$C C T 3$ & Down \\
$T L R 4$ & Up \\
$T U B B$ & Down \\
$F C G R 2 A$ & Up \\
$K L R D 1$ & Down \\
$F A S N$ & Down \\
\hline
\end{tabular}

were found to be TUNEL-positive (39). These results indicate that upregulation of the p53 gene may result in chronic inflammation and apoptosis in RA patients. In addition, other members of the AIMP families, such as AIMP1, were also found to promote the expression of pro-inflammatory genes in monocytes/macrophages and dendritic cells (40) and induce cytokine (i.e. TNF- $\alpha$ )-dependent apoptosis (41). The antibody atliximab was reported to neutralize the expression of AIMP1 and then block the AIMP1-mediated production of inflammatory cytokines, ultimately attenuating collagen-induced arthritis (42). Accordingly, we speculate that EEF1E1 may also be involved in inflammation of AS by upregulating p53 and pro-inflammatory cytokines. In line with this hypothesis, our results showed that EEF1E1 was upregulated in the whole blood of AS patients compared with the control. Upregulation of EEF1E1 may be attributed to genetic mutations (rs7763907 and rs7751386) since the LRR of AS was significantly higher than that of controls and the genotype and allele frequencies were significantly different. However, further experimental validation is needed as studies investigating the SNPs of EEF1E1 are limited apart from the study of Liu et al that showed the number of risk alleles of rs12199241 in AIMP3 to be significantly associated with high DNA damage level (43).

SERPINA1 is a gene that encodes alpha-1-antitrypsin (AAT). It was found that the AAT concentration was higher in AS patients under active phase than the patients with remission/partial remission (44). In addition, the carboxyl terminal fragment of AAT was demonstrated to significantly induce the production of pro-inflammatory molecules (gelatinase B, monocyte chemoattractant protein-1 and IL-6) in human monocytes by interactions with the CD36 scavenger receptor and low density lipoprotein (LDL) receptor (45). These findings suggest that SERPINA1 may be a potential biomarker for the diagnosis of AS and evaluation of the efficacy of treatment by influencing inflammation. In line with these studies, we also found that SERPINA1 was upregulated in AS patients and it participated in GO terms 


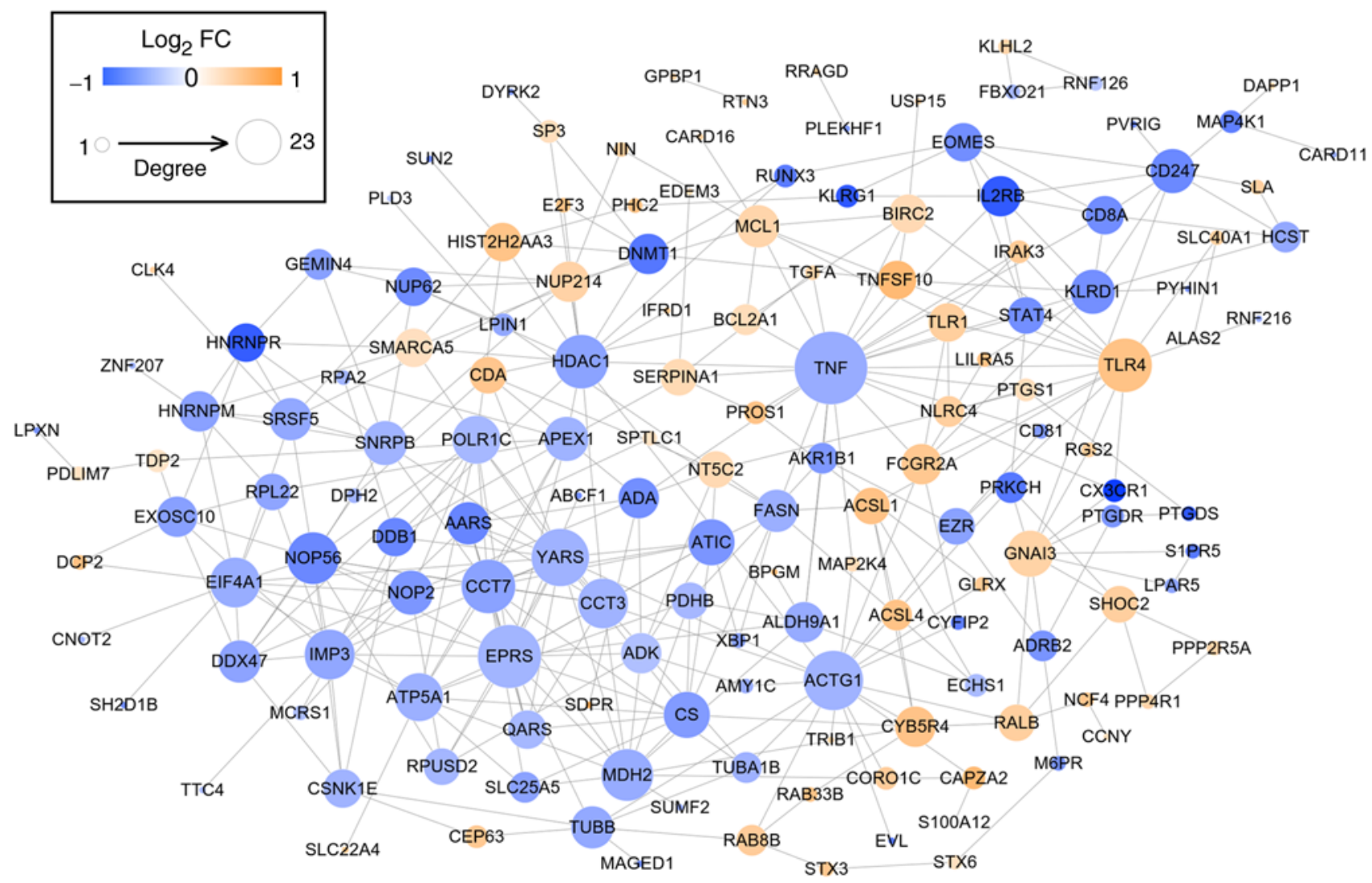

Figure 4. Protein-protein interaction network using the common differentially expressed genes in the two mRNA expression profile datasets (GSE73754 and GSE25101). The network is constructed using the interaction data from the STRING 10.0 database via the Cytoscape software. Orange, upregulated; blue, downregulated. The larger size of the node (protein) indicates a higher degree (interaction relationships). FC, fold change; STRING, Search Tool for the Retrieval of Interacting Genes.

A

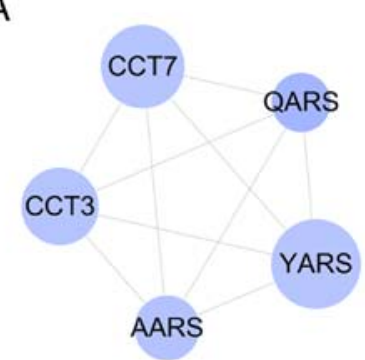

C

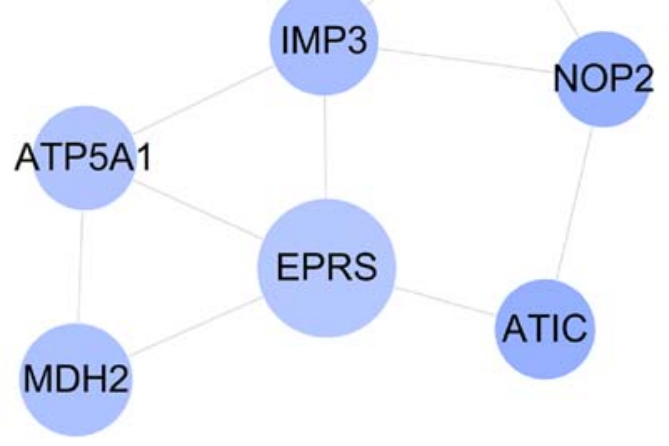

DDX47
B

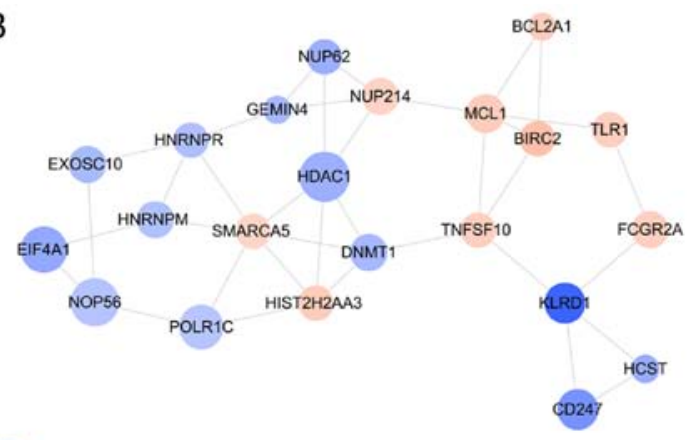

D

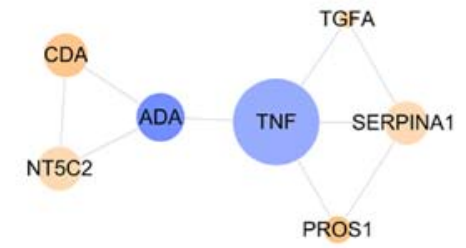

Figure 5. Modules extracted from the protein-protein interaction network. (A) Module 1; (B) Module 2; (C) Module 3; (D) Module 4. The modules are extracted using Molecular Complex Detection (MCODE) plugin of Cytoscape software. Orange, upregulated; blue, downregulated. The larger size of the node (protein) indicates the higher degree (interaction relationships). 
Table IV. Function enrichment for genes in modules.

\begin{tabular}{|c|c|c|c|c|}
\hline & Category & Term & P-value & Genes \\
\hline \multirow[t]{9}{*}{1} & KEGG_PATHWAY & hsa00970:Aminoacyl-tRNA biosynthesis & 8.99E-05 & $Y A R S, A A R S, Q A R S$ \\
\hline & GOTERM_BP_DIRECT & $\begin{array}{l}\text { GO:0006418 tRNA aminoacylation } \\
\text { for protein translation }\end{array}$ & $3.31 \mathrm{E}-05$ & $Y A R S, A A R S, Q A R S$ \\
\hline & GOTERM_BP_DIRECT & GO:0006457 protein folding & $6.76 \mathrm{E}-04$ & $C C T 7, A A R S, C C T 3$ \\
\hline & GOTERM_BP_DIRECT & $\begin{array}{l}\text { GO: } 1904871 \sim \text { positive regulation } \\
\text { of protein localization to Cajal body }\end{array}$ & $1.90 \mathrm{E}-03$ & СCT7, СCT3 \\
\hline & GOTERM_BP_DIRECT & $\begin{array}{l}\text { GO:1904874 positive regulation of } \\
\text { telomerase RNA localization to Cajal body }\end{array}$ & $3.57 \mathrm{E}-03$ & CCT7, СCT3 \\
\hline & GOTERM_BP_DIRECT & $\begin{array}{l}\text { GO:0032212 positive regulation of } \\
\text { telomere maintenance via telomerase }\end{array}$ & $7.60 \mathrm{E}-03$ & ССТ7, ССТ3 \\
\hline & GOTERM_BP_DIRECT & $\begin{array}{l}\text { GO:0007339 binding of sperm to } \\
\text { zona pellucida }\end{array}$ & $8.31 \mathrm{E}-03$ & CCT7, СCT3 \\
\hline & GOTERM_BP_DIRECT & GO:1901998 toxin transport & $8.55 \mathrm{E}-03$ & CCT7, СCT3 \\
\hline & GOTERM_BP_DIRECT & GO:0050821 protein stabilization & $3.20 \mathrm{E}-02$ & СCT7, ССТ3 \\
\hline \multirow[t]{12}{*}{2} & KEGG_PATHWAY & $\begin{array}{l}\text { hsa04650: Natural killer cell } \\
\text { mediated cytotoxicity }\end{array}$ & $4.23 \mathrm{E}-03$ & TNFSF10, CD247, KLRD1, HCST \\
\hline & KEGG_PATHWAY & hsa03013:RNA transport & $1.10 \mathrm{E}-02$ & NUP214, NUP62, EIF4A1, GEMIN4 \\
\hline & GOTERM_BP_DIRECT & $\begin{array}{l}\text { GO:0007166 cell surface receptor } \\
\text { signaling pathway }\end{array}$ & $3.33 \mathrm{E}-04$ & $\begin{array}{l}\text { TNFSF10, NUP62, CD247, BIRC2, } \\
\text { KLRD1 }\end{array}$ \\
\hline & GOTERM_BP_DIRECT & GO:0016032 viral process & 4.64E-04 & $\begin{array}{l}\text { NUP214, NUP62, HDAC1, CD247, } \\
\text { EIF4A1 }\end{array}$ \\
\hline & GOTERM_BP_DIRECT & $\begin{array}{l}\text { GO:0043066 negative regulation } \\
\text { of apoptotic process }\end{array}$ & $2.21 \mathrm{E}-03$ & $\begin{array}{l}\text { MCL1, NUP62, HDAC1, BCL2A1, } \\
\text { BIRC2 }\end{array}$ \\
\hline & GOTERM_BP_DIRECT & $\begin{array}{l}\text { GO:0043123 positive regulation } \\
\text { of I-kappaB kinase/NF-kappaB signaling }\end{array}$ & $1.70 \mathrm{E}-02$ & TNFSF10, NUP62, BIRC2 \\
\hline & GOTERM_BP_DIRECT & $\begin{array}{l}\text { GO:0050776 regulation of immune } \\
\text { response }\end{array}$ & $2.06 \mathrm{E}-02$ & $C D 247, K L R D 1, H C S T$ \\
\hline & GOTERM_BP_DIRECT & $\begin{array}{l}\text { GO:0043044 ATP-dependent } \\
\text { chromatin remodeling }\end{array}$ & $2.84 \mathrm{E}-02$ & HDAC1, SMARCA5 \\
\hline & GOTERM_BP_DIRECT & GO:0006364 rRNA processing & $2.90 \mathrm{E}-02$ & EXOSC 10, NOP56, GEMIN4 \\
\hline & GOTERM_BP_DIRECT & $\begin{array}{l}\text { GO:0006409 tRNA export from } \\
\text { nucleus }\end{array}$ & $3.93 \mathrm{E}-02$ & NUP214, NUP62 \\
\hline & GOTERM_BP_DIRECT & $\begin{array}{l}\text { GO:0010827 regulation of glucose } \\
\text { transport }\end{array}$ & $4.05 \mathrm{E}-02$ & NUP214, NUP62 \\
\hline & GOTERM_BP_DIRECT & $\begin{array}{l}\text { GO:0097192 extrinsic apoptotic } \\
\text { signaling pathway in absence of ligand }\end{array}$ & 4.17E-02 & $M C L 1, B C L 2 A 1$ \\
\hline \multirow[t]{4}{*}{3} & KEGG_PATHWAY & hsa01100:Metabolic pathways & $1.94 \mathrm{E}-02$ & ATIC, EPRS, ATP5A1, MDH2 \\
\hline & GOTERM_BP_DIRECT & $\begin{array}{l}\text { GO:0006888 ER to Golgi } \\
\text { vesicle-mediated transport }\end{array}$ & $1.32 \mathrm{E}-03$ & TGFA, SERPINA1, PROS1 \\
\hline & GOTERM_BP_DIRECT & $\begin{array}{l}\text { GO:0048566 embryonic digestive } \\
\text { tract development }\end{array}$ & $5.70 \mathrm{E}-03$ & $T N F, A D A$ \\
\hline & GOTERM_BP_DIRECT & GO:0048208 COPII vesicle coating & $2.16 \mathrm{E}-02$ & TGFA, SERPINAI \\
\hline \multirow[t]{3}{*}{4} & GOTERM_BP_DIRECT & GO:0002576 platelet degranulation & $3.62 \mathrm{E}-02$ & SERPINA1, PROS1 \\
\hline & GOTERM_BP_DIRECT & GO:0000187 activation of MAPK activity & $3.76 \mathrm{E}-02$ & $T N F, T G F A$ \\
\hline & GOTERM_BP_DIRECT & $\begin{array}{l}\text { GO:0010951 negative regulation } \\
\text { of endopeptidase activity }\end{array}$ & $4.25 \mathrm{E}-02$ & SERPINA1, PROS1 \\
\hline
\end{tabular}

KEGG, Kyoto encyclopedia of Genes and Genomes; GO, Gene Ontology; BP, biological process.

of platelet degranulation. Platelet-specific degranulation gene Munc13-4 knockout mice were shown to display a reduction in airway hyper-responsiveness and eosinophilic inflammation, indirectly confirming the pro-inflammatory roles of SERPINA1 in AS (46). Importantly, a study was conducted to use TaqMan method to genotype tag SNPs (rs2753934, 
Table V. Genotype and allele frequency of SNP loci for SERPINA1 and EEF1E1.

\begin{tabular}{|c|c|c|c|c|c|c|c|c|c|}
\hline \multirow[b]{2}{*}{ Genes } & \multirow[b]{2}{*}{ SNP } & & \multicolumn{3}{|c|}{ Genotype } & & \multicolumn{3}{|c|}{ Allele } \\
\hline & & & AS & Control & P-value & & AS & Control & $\mathrm{P}$-value \\
\hline \multirow[t]{3}{*}{ SERPINA1 } & \multirow[t]{3}{*}{ rs6575424 } & AA & 9 & 12 & \multirow[t]{3}{*}{0.077} & $\mathrm{~A}$ & 25 & 79 & \multirow[t]{3}{*}{0.665} \\
\hline & & $\mathrm{AB}$ & 16 & 67 & & $\mathrm{~B}$ & 42 & 151 & \\
\hline & & $\mathrm{BB}$ & 26 & 84 & & & & & \\
\hline \multirow[t]{13}{*}{ EEF1E1 } & \multirow[t]{4}{*}{ rs7763907 } & $\mathrm{AB}$ & 1 & 0 & \multirow[t]{4}{*}{$<0.001$} & $\mathrm{~A}$ & 4 & 4 & \multirow[t]{4}{*}{0.047} \\
\hline & & $\mathrm{BB}$ & 13 & 5 & & $\mathrm{~B}$ & 14 & 5 & \\
\hline & & $\mathrm{NC}$ & 37 & 154 & & & & & \\
\hline & & AA & 0 & 4 & & & & & \\
\hline & \multirow[t]{2}{*}{ rs9328453 } & $\mathrm{AB}$ & 0 & 3 & \multirow[t]{2}{*}{1.000} & $\mathrm{~A}$ & 0 & 3 & \multirow[t]{2}{*}{1.000} \\
\hline & & $\mathrm{BB}$ & 51 & 163 & & $\mathrm{~B}$ & 51 & 166 & \\
\hline & \multirow[t]{4}{*}{ rs7751386 } & AA & 7 & 2 & \multirow[t]{4}{*}{$<0.001$} & $\mathrm{~A}$ & 12 & 41 & \multirow[t]{4}{*}{1.000} \\
\hline & & $\mathrm{AB}$ & 5 & 39 & & $\mathrm{~B}$ & 25 & 80 & \\
\hline & & $\mathrm{BB}$ & 20 & 41 & & & & & \\
\hline & & $\mathrm{NC}$ & 19 & 81 & & & & & \\
\hline & \multirow[t]{3}{*}{ rs12660697 } & AA & 0 & 1 & \multirow[t]{3}{*}{0.631} & $\mathrm{~A}$ & 4 & 10 & \multirow[t]{3}{*}{0.749} \\
\hline & & $\mathrm{AB}$ & 4 & 9 & & B & 51 & 162 & \\
\hline & & $\mathrm{BB}$ & 47 & 153 & & & & & \\
\hline
\end{tabular}

SNP, single nucleotide polymorphism; AS, ankylosing spondylitis.
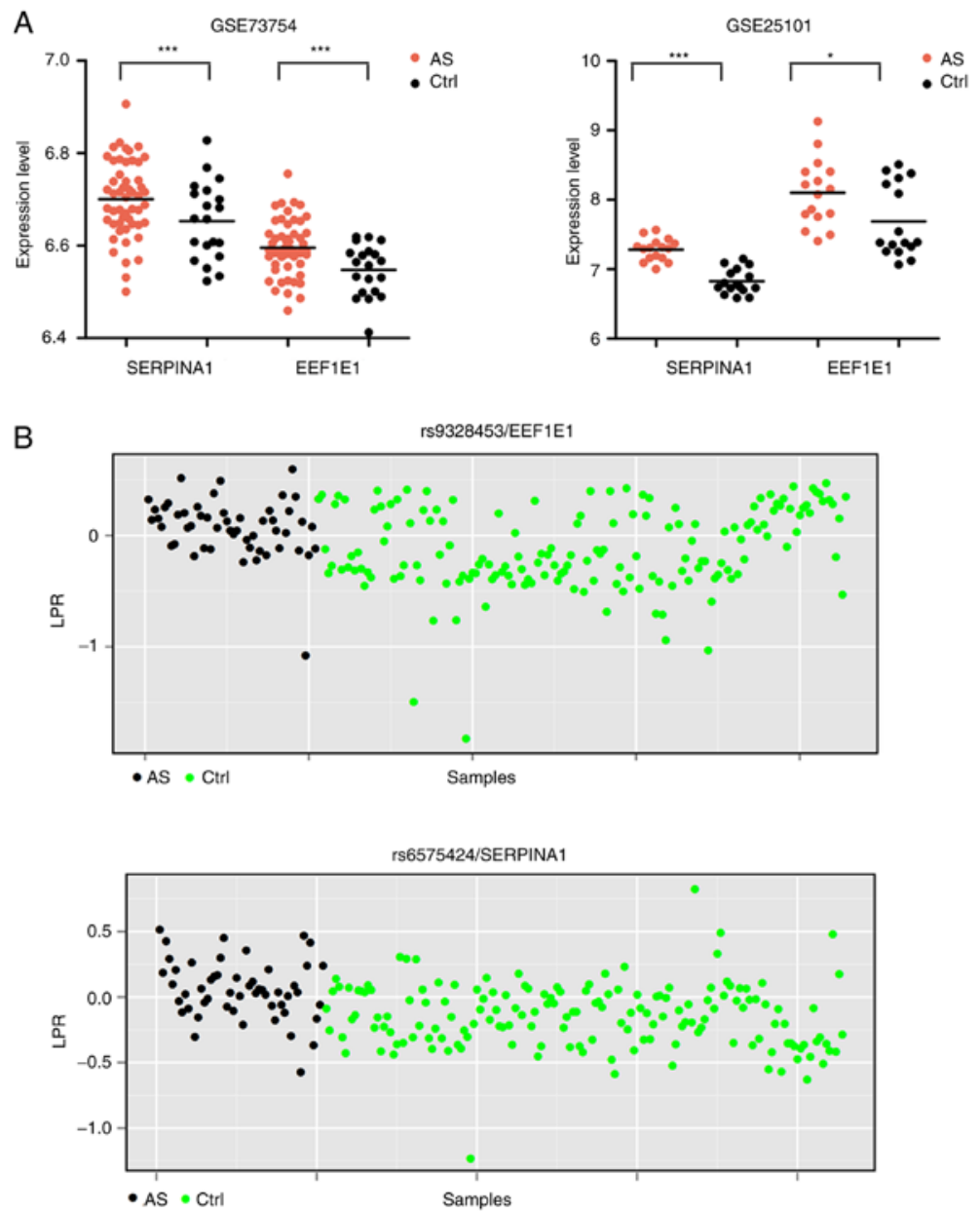

Figure 6. The expression levels and LRR of SNP loci of EEF1E1 and SERPINA1. (A) The expression levels of EEF1E1 and SERPINA1 in blood samples of GSE73754 (AS: $n=52$; Ctrl: $n=20$ ) and GSE25101 (AS: $n=16$; Ctrl: $n=20$ ) datasets, respectively. ${ }^{*}<0.05 ;{ }^{* * * *} \mathrm{P}<0.001$. (B) LRR of SNPs in blood samples of GSE39428 (AS: $n=51 ; C t r l: n=163$ ). Only the most significant SNPs were displayed. The t-test was used to determine the difference in expression and LRR between AS and Ctrl. AS, ankylosing spondylitis; Ctrl, control; LRR, Log R ratios; SNP, single nucleotide polymorphism. 
rs2749531 and rs6575424) in SERPINA1 of 56 AS cases and 160 healthy controls. The results revealed an increased expression of AAT in synovial membranes of AS compared with control samples, but no significant association was observed between the AAT polymorphism and AS (47). This also seems to be in accordance with our results and indicates that SERPINA1 may not be a genetically related biomarker for AS.

However, there were some limitations to the present study. First, this study was only performed to preliminarily screen the potential genetic biomarkers for AS. Further experiments are necessary, including clinical confirmation of the association between the polymorphism of EEFIE1 and SERPINAI and the risk of AS and patient prognosis; clinical validation of the expression of EEF1E1 and SERPINA1; clinical (correlation analysis), in vitro (site-directed mutagenesis to construct the expression vector with different alleles, transfection of monocytes or osteoblasts followed by detection of cell proliferation, inflammatory factor release or mineralization) and in vivo (mutation knockout in animal models followed by assessment of histology and bone joint) verification of the association between gene polymorphisms and their expressions as well as corresponding phenotypic changes. Second, the SNP microarray used in this study only analyzed the SNPs in specific 384 genes, but not all the genes. Additional SNP discovery by deep sequencing with a larger sample size is essential to obtain more genetic biomarkers.

In conclusion, our findings preliminarily suggest that EEF1E1 may be an underlying novel, important genetic biomarker for the diagnosis of AS. Its rs7763907 and rs7751386 polymorphisms may lead to its upregulated expression and then promote the transcription of $\mathrm{p} 53$ and pro-inflammatory cytokines, leading to the development of AS.

\section{Acknowledgements}

Not applicable.

\section{Funding}

No funding was received.

\section{Availability of data and materials}

The microarray data GSE73754 (https://www.ncbi.nlm. nih.gov/geo/query/acc.cgi?acc=GSE73754), GSE25101 (https://www.ncbi.nlm.nih.gov/geo/query/acc.cgi?acc=GSE25101) and GSE39428 (https://www.ncbi.nlm.nih.gov/geo/query/acc. cgi?acc=GSE39428) were downloaded from the GEO database in NCBI.

\section{Authors' contributions}

XF was involved in the conception and design, analysis and interpretation of data and drafted the initial manuscript. BQ collected the data. LM and FM contributed to the interpretation of the data. BQ, LM and FM revised the manuscript critically for important intellectual content. All authors read and approved the manuscript and agree to be accountable for all aspects of the research in ensuring that the accuracy or integrity of any part of the work are appropriately investigated and resolved.

\section{Ethics approval and consent to participate}

Not applicable.

\section{Patient consent for publication}

Not applicable.

\section{Competing interests}

The authors declare that they have no competing interests.

\section{References}

1. Dean LE, Jones GT, MacDonald AG, Downham C, Sturrock RD and Macfarlane GJ: Global prevalence of ankylosing spondylitis. Rheumatology (Oxford) 53: 650-657, 2014.

2. Healey EL, Haywood KL, Jordan KP, Garratt AM and Packham JC: Patients with well-established ankylosing spondylitis show limited deterioration in a ten-year prospective cohort study. Clin Rheumatol 32: 67-72, 2013.

3. Chen B, Li J, He C, Li D, Tong W, Zou Y and Xu W: Role of HLA-B27 in the pathogenesis of ankylosing spondylitis. Mol Med Rep 15: 1943-1951, 2017.

4. Fernández-Sueiro JL, Alonso C, Blanco FJ, Rodríguez-Gómez M, Galdo F and González-Gay MA: Prevalence of HLA-B27 and subtypes of HLA-B27 associated with ankylosing spondylitis in Galicia, Spain. Clin Exp Rheumatol 22: 465-468, 2004.

5. Cauli A, Dessole G, Fiorillo MT, Vacca A, Mameli A, Bitti P, Passiu G, Sorrentino R and Mathieu A: Increased level of HLA-B27 expression in ankylosing spondylitis patients compared with healthy HLA-B27-positive subjects: A possible further susceptibility factor for the development of disease. Rheumatology (Oxford) 41(12): 1375-1379, 2002.

6. Yang T, Duan Z, Wu S, Liu S, Zeng Z, Li G, Wang S, Fan D, Ye D, Xu S, et al: Association of HLA-B27 genetic polymorphisms with ankylosing spondylitis susceptibility worldwide: A meta-analysis. Mod Rheumatol 24: 150-161, 2014.

7. Lin $\mathrm{H}$ and Gong YZ: Association of HLA-B27 with ankylosing spondylitis and clinical features of the HLA-B27-associated ankylosing spondylitis: A meta-analysis. Rheumatol Int 37: 1267-1280, 2017.

8. Kim TJ, Na KS, Lee HJ, Lee B and Kim TH: HLA-B27 homozygosity has no influence on clinical manifestations and functional disability in ankylosing spondylitis. Clin Exp Rheumatol 27: 574-579, 2009.

9. Zhang L, Zhang YJ, Chen J, Huang XL, Fang GS, Yang LJ, Duan Y and Wang J: The association of HLA-B27 and Klebsiella pneumoniae in ankylosing spondylitis: A systematic review. Microb Pathog 117: 49-54, 2018.

10. Brown MA, Kennedy LG, Macgregor AJ, Darke C, Duncan E, Shatford JL, Taylor A, Calin A and Wordsworth P: Susceptibility to ankylosing spondylitis in twins: The role of genes, HLA, and the environment. Arthritis Rheum 40: 1823-1828, 1997.

11. Brophy S, Hickey S, Menon A, Taylor G, Bradbury L, Hamersma J and Calin A: Concordance of disease severity among family members with ankylosing spondylitis? J Rheumatol 31: 1775-1778, 2004.

12. Azevedo VF, Faria-Neto JR, Stinghen A, Lorencetti PG, Miller WP, Gonçalves BP, Szyhta CC and Pecoits-Filho R: IL-8 but not other biomarkers of endothelial damage is associated with disease activity in patients with ankylosing spondylitis without treatment with anti-TNF agents. Rheumatol Int 33: 1779-1783, 2013.

13. Gonza-Lezlopez L, Fajardo-Robledo NS, Saldaña-Cruz AM, Moreno-Sandoval IV, Bonilla-Lara D, Zavaleta-Muñiz S, Nava-Zavala AH, Hernandez-Cuervo P, Rocha-Muñoz A, Rodriguez-Jimenez NA, et al: Association of adipokines, interleukin-6, and tumor necrosis factor- $\alpha$ concentrations with clinical characteristics and presence of spinal syndesmophytes in patients with ankylosing spondylitis: A cross-sectional study. J Int Med Res 45: 1024-1035, 2017. 
14. Sundström B, Ljung L and Wållberg-Jonsson S: Exercise habits and C-reactive protein may predict development of spinal immobility in patients with ankylosing spondylitis. Clin Rheumatol 37: 2881-2885, 2018

15. Sohn DH, Jeong H, Roh JS, Lee HN, Kim E, Koh JH and Lee SG: Serum CCL11 level is associated with radiographic spinal damage in patients with ankylosing spondylitis. Rheumato Int 38: 1455-1464, 2018

16. Ruan WF, Xie JT, Jin Q, Wang WD and Ping AS: The diagnostic and prognostic role of interleukin $12 \mathrm{~B}$ and interleukin $6 \mathrm{R}$ gene polymorphism in patients with ankylosing spondylitis. J Clin Rheumatol 24: 18-24, 2018.

17. Ma HJ, Yin QF, Wu Y and Guo MH: TNF- $\alpha-308$ polymorphism determines clinical manifestations and therapeutic response of ankylosing spondylitis in Han chinese. Med Clin (Barc) 149: 517-522, 2017.

18. Gracey E, Yao Y, Green B, Qaiyum Z, Baglaenko Y, Lin A, Anton A, Ayearst R, Yip P and Inman RD: Sexual dimorphism in the Th17 signature of ankylosing spondylitis. Arthritis Rheumatol 68: 679-689, 2015.

19. Pimentel-Santos FM, Ligeiro D, Matos M, Mourão AF, Costa J, Santos H, Barcelos A, Godinho F, Pinto P, Cruz M, et al: Whole blood transcriptional profiling in ankylosing spondylitis identifies novel candidate genes that might contribute to the inflammatory and tissue-destructive disease aspects. Arthritis Res Ther 13: R57, 2011.

20. Chang X, Xu B, Wang L, Wang Y, Wang Y and Yan S: Investigating a pathogenic role for TXNDC5 in tumors. Int J Oncol 43: 1871-1884, 2013

21. Chang X, Zheng Y, Yang Q, Wang L, Pan J, Xia Y, Yan X and Han J: Carbonic anhydrase I (CA1) is involved in the process of bone formation and is susceptible to ankylosing spondylitis Arthritis Res Ther 14: R176, 2012.

22. Ritchie ME, Phipson B, Wu D, Hu Y, Law CW, Shi W and Smyth GK: limma powers differential expression analyses for RNA-sequencing and microarray studies. Nucleic Acids Res 43 e47, 2015 .

23. Wang K, Li M, Hadley D, Liu R, Glessner J, Grant SFA, Hakonarson $\mathrm{H}$ and Bucan M: PennCNV: An integrated hidden Markov model designed for high-resolution copy number variation detection in whole-genome SNP genotyping data. Genome Res 17: 1665-1674, 2007.

24. Benjamini Y, Drai D, Elmer G, Kafkafi N and Golani I: Controlling the false discovery rate in behavior genetics research. Behav Brain Res 125: 279-284, 2001.

25. Szklarczyk D, Franceschini A, Wyder S, Forslund K, Heller D, Huerta-Cepas J, Simonovic M, Roth A, Santos A, Tsafou KP, et al: STRING v10: Protein-protein interaction networks, integrated over the tree of life. Nucleic Acids Res 43(Database Issue) D447-D452, 2015.

26. Kohl M, Wiese S and Warscheid B: Cytoscape: Software for visualization and analysis of biological networks. Methods Mol Biol 696: 291-303, 2011.

27. Tang Y, Li M, Wang J, Pan Y and Wu FX: CytoNCA: A cytoscape plugin for centrality analysis and evaluation of protein interaction networks. Biosystems 127: 67-72, 2015.

28. Bader GD and Hogue CW: An automated method for finding molecular complexes in large protein interaction networks. BMC Bioinformatics 4: 2, 2003.

29. $\mathrm{Ku} \mathrm{MJ}$ and Lee SY: Contributions of aminoacyl-tRNA synthetase-interacting multifunctional protein-3 to mammalian translation initiation. Amino Acids 44: 1241-1245, 2013.

30. Kang T, Kwon NH, Lee JY, Park MC, Kang E, Kim HH, Kang TJ and Kim S: AIMP3/p18 controls translational initiation by mediating the delivery of charged initiator tRNA to initiation complex. J Mol Biol 423: 475-481, 2012.

31. Hassan MK, Kumar D, Naik M and Dixit M: The expression profile and prognostic significance of eukaryotic translation elongation factors in different cancers. PLoS One 13: e0191377, 2018.
32. Yu X, Zheng H, Chan MT and Wu WK: HULC: An oncogenic long non-coding RNA in human cancer. J Cell Mol Med 21: 410-417, 2017.

33. Kim SS, Hur SY, Kim YR, Yoo NJ and Lee SH: Expression of AIMP1, 2 and 3, the scaffolds for the multi-tRNA synthetase complex, is downregulated in gastric and colorectal cancer. Tumori 97: 380-385, 2011.

34. Park BJ, Oh YS, Park SY, Choi SJ, Rudolph C, Schlegelberger B and Kim S: AIMP3 haploinsufficiency disrupts oncogene-induced p53 activation and genomic stability. Cancer Res 66: 6913-6918, 2006.

35. Han JM, Park BJ, Sang GP, Oh YS, Choi SJ, Sang WL, Hwang SK, Chang SH, Cho MH and Kim S: AIMP2/p38, the scaffold for the multi-tRNA synthetase complex, responds to genotoxic stresses via p53. Proc Natl Acad Sci USA 105: 11206-11211, 2008.

36. Gurung PM, Veerakumarasivam A, Williamson M, Counsell N, Douglas J, Tan WS, Feber A, Crabb SJ, Short SC, Freeman A, et al: Loss of expression of the tumour suppressor gene AIMP3 predicts survival following radiotherapy in muscle-invasive bladder cancer. Int J Cancer 136: 709-720, 2015.

37. Lee S, Yu KR, Ryu YS, Oh YS, Hong IS, Kim HS, Lee JY, Kim S, Seo KW and Kang KS: miR-543 and miR-590-3p regulate human mesenchymal stem cell aging via direct targeting of AIMP3/p18. Age (Dordr) 36: 9724, 2014

38. Abou-Shousha SA, Salah E and Wagdy E: Study of P53 in peripheral blood and synovial mononuclear cells of rheumatoid arthritis and osteoarthritis patients and its relation to the degree of disease activity. Egypt J Immunol 12: 61-70, 2005.

39. Chou CT, Yang JS and Lee MR: Apoptosis in rheumatoid arthritis-expression of Fas, Fas-L, p53, and Bcl-2 in rheumatoid synovial tissues. J Pathol 193: 110-116, 2015.

40. Liang D, Halpert MM, Konduri V and Decker WK: Stepping out of the cytosol: AIMp1/p43 potentiates the link between innate and adaptive immunity. Int Rev Immunol 34: 367-381, 2015.

41. Choi JW, Kim DG, Park MC, Um JY, Han JM, Park SG, Choi EC and Kim S: AIMP2 promotes TNFalpha-dependent apoptosis via ubiquitin-mediated degradation of TRAF2. J Cell Sci 122: 2710-2715, 2009

42. Hong SH, Cho JG, Yoon KJ, Lim DS, Kim CH, Lee SW and Park SG: The antibody atliximab attenuates collagen-induced arthritis by neutralizing AIMP1, an inflammatory cytokine that enhances osteoclastogenesis. Biomaterials 44: 45-54, 2015.

43. Liu J, Zhu M, Chen W, Xie K, Shen W, Yuan J, Cheng Y, Geng L, Wang Y, Jin G, et al: Genetic variants in multisynthetase complex genes are associated with DNA damage levels in chinese populations. Mutat Res 786: 8-13, 2016.

44. Ozgocmen S, Godekmerdan A and Ozkurt-Zengin F: Acute-phase response, clinical measures and disease activity in ankylosing spondylitis. Joint Bone Spine 74: 249-253, 2007.

45. Janciauskiene S, Moraga F and Lindgren S: C-terminal fragment of alpha1-antitrypsin activates human monocytes to a pro-inflammatory state through interactions with the CD36 scavenger receptor and LDL receptor. Atherosclerosis 158: 41-51, 2001.

46. Cardenas EI, Breaux K, Da Q, Flores JR, Ramos MA, Tuvim MJ, Burns AR, Rumbaut RE and Adachi R: Platelet Munc13-4 regulates hemostasis, thrombosis and airway inflammation. Haematologica 103: 1235-1244, 2018.

47. Sun S, Fang K, Zhao Y, Yan X and Chang X: Increased expression of alpha 1-anti-trypsin in the synovial tissues of patients with ankylosing spondylitis. Clin Exp Rheumatol 30: 39-44, 2012

This work is licensed under a Creative Commons Attribution-NonCommercial-NoDerivatives 4.0 International (CC BY-NC-ND 4.0) License. 